\title{
$\mathrm{KrF}$ エキシマレーザを用いたグラファイトアブレーションの レーザプラズマプルーム特性
}

\author{
正員青木振一（熊本工業大学） \\ 正員池上知顯 (熊本大学) \\ 正員蛯原健治 (熊本大学)
}

\section{Characteristics of Laser Plasma Plume from Graphite Target Ablation Using KrF Excimer Laser}

\author{
Shin-ichi Aoqui, Member (Kumamoto Institute of Technology) \\ Tomoaki Ikegami, Kenji Ebihara, Member (Kumamoto University)
}

\begin{abstract}
We have optically studied the dynamics of the plasma plume during preparation of diamondlike carbon (DLC) thin films and carbon nitride $(\mathrm{CNx})$ thin films by the pulsed laser deposition method. We report on spectroscopic properties of laser plasma plume produced during the DLC and $\mathrm{CNx}$ thin film deposition. It was found that carbon atoms and ions emitted from the target react with ambient gases of hydrogen and nitrogen. $\mathrm{CH}$ and $\mathrm{CN}$ molecules are formed in the gas phase. The properties of DLC and $\mathrm{CNx}$ thin films are strongly affected by the laser plume dynamics. Some conversion mechanism of $\mathrm{C}_{2}$ radical to $\mathrm{CN}$ radical probably exists.
\end{abstract}

キ一ワード : レーザアブレーション, DLC薄膜, $\mathrm{CNx}$ 薄膜, 発光分光法, プラズマプルーム

\section{1. まえがき}

ダイヤモンドは硬く透明で熱伝導率が高いなど魅力的な 性質を備えている。近年はそのダイヤモンドの特性にせま り，更に越えるような物質の開発研究が行われている。軽 元素であるボロン，炭素，空素からなる新材料はダイヤモ ンド関連物質として注目を集めている。このようなダイヤ モンドライクな性質をもつ物筫の薄膜は，ハードコーティ ングやデバイス保護膜などへの応用や電界電子放出源, ドー ピングによるカーボン半導体デバイスへの応用などが期待 されている ${ }^{(\mathrm{I})}$ 。近年, これらの高硬度薄膜を作製するため にささまざまなプロセスが研究・開発されている。例えば, CVD法やスパッ夕法, パルス・レーザデポジション (pulsed laserdeposition:PLD法) などである(2)-(4)。いずれのプロセス においても，成膜のどの段階でどのような物質が存在して いるかを調べることが，膜貿の改善に慗がる。

我々はPLD法を用いて，ダイヤモンド状炭素 (Diamondlikecabon:DLC) およびCNx 溥膜の作製の研究を 行ってきた ${ }^{(5)}$ 。本論文ではグラファイトをターゲットとし たレーザアブレーションにおいて，レーザプラズマプルー ム中にどのような発光粒子種が存在するかを，成膜時の最 適条件を考虑しながら発光分光法により測定した。
PLD法ではターゲットから放出される粒子と背景ガスとの 気相反応は薄膜特性を知る手がかりとなる。パルスレーザ をグラファイトターゲットに入射することにより，レーザ プラズマプルームが発生する。プラズマプルームは放出粒 子と背景ガス種や圧力により大きく変わる ${ }^{(6)-(8)}$ 。生成された プラズマプルームは熱的な作用だけでは無く，衝突解離／ 電離作用，光吸収作用も関与しレーザ波長によっても状態 が大きく変わる ${ }^{(9) \cdot(11)}$ 。グラファイトターゲットを用いた薄 膜は，様々な研究がなされおり，特にプラズマプルーム中 $\sigma \mathrm{C}_{2}$ の生成が成膜に関係する事が指摘されている ${ }^{(12)-(14)}$ 。例 えば, グラファイトのアブレーションに関しKokaiはレーザ 波長が $1064 \mathrm{~nm}$ と266nm で発光種が大きく異なることを示し $た^{(11),(15)}$ 。赤外レーザではC 2 分子発光が確認されるのに対し， 紫外レーザではC.C゙などの原子，イオンの発光が中心とな るとしている。紫外レーザの結果に関しては我々の KrFエキ シマレーザにおける分光測定と同様な結果となっている。

成膜においては以下の 3 段階の過程を経る。まず,タ一 ゲット面上でレーザ光による光吸収反応と熱的反応で夕一 ゲットより粒子が放出される。次にアブレーション粒子の 才学的運動工ネルギ一により，ガスとの衝突で解離／電離， 再結合が起こる。最後に基板の表面状態，温度，ガスの作 用により原子や分子が結合し，基板上に薄膜が堆積する。 
プルームの発光スペクトル測定条件としてターゲット面 沽の位圏, ガス種, レーザフルエンスなどを変化させ, $\mathrm{C}_{1} \mathrm{C}^{+}, \mathrm{C}_{2}, \mathrm{CH}_{2} \mathrm{CH}^{+}, \mathrm{C}_{2} \mathrm{H}, \mathrm{CN}, \mathrm{N}_{2}$ および $\mathrm{H} \alpha$ 同定し，更に時間発 展波形より粒子の飛行速度を求めた。また $\alpha \alpha$ シュタルク 広がりから電子密度を求めた。同時成膜ではガス種により, DLCおよびCNx薄膜が堆積する。薄膜組成の結合状態を赤外 吸収特性から調ベ, プルーム中の分子種上の比較より最適 なアブレーション条件に於けるプルームの状熊を調べた。 DLCでは最適な可視透過率のデポジション条件で観測を行つ た。

\section{2. 実験装置}

図 1 に実験に用いた分光測定装置の概略を示す。真空容 器はステンレス製で複合ターボ分子ポンプにより到達真空 度5.0×107 Tor まで排気され，高純度カス（窒素，水素，へ リウム）をマスフローメータで真空容器に導入する。ター ゲットは30mm径のグラファイト・カーボン（純度99.999\%) を回転機構を備えたターゲットホルダーに取り付けた。 KrF エキシマレーザ (LambdaPhysik Model LPX305icc，最大エネ ルギー850mJ、 $\lambda=248 \mathrm{~nm}$, パルス幅25ns）を用いて，レーザ 光はターゲットに対して窒素及びへリウムガス導入の場合 は90 に入射した。水素ガスの場合は $45^{\circ}$ で入射した。レー ザ入射角 $90^{\circ}$ の場合は，実験装置の幾何学的配置より，夕ー ゲット表面から垂直方向への測定距離が十分大きくとれる。 しかし，測定と同時成膜は出来ない。分光測定之同時成膜

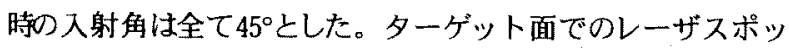

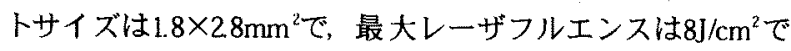
ある。プラズマプルームの観測は $250 \mathrm{~mm}$ のノクロメータ ヒコン製P-250）を用いて波長330〜800nmの範囲で行った。

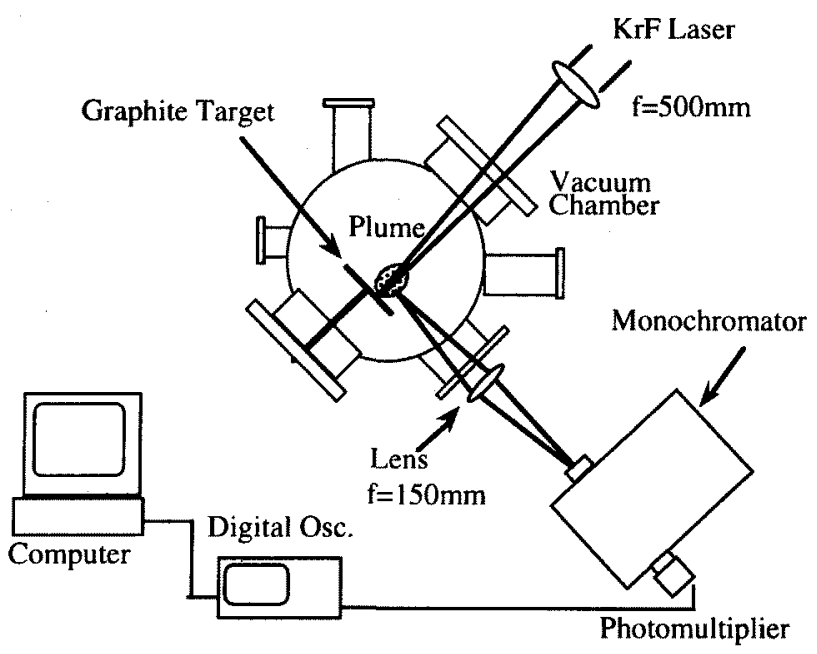

図1 PLD装置及び光学測定装置

Fig.1. Schematic of the PLD and optical measurement system.
プラズマプルームの発光はターゲット表面上 $\mathrm{d}=1 \mathrm{~mm}$ から垂 直方向 $30 \mathrm{~mm}$ まで観測した。各点の発光は $\mathrm{f}=150 \mathrm{~mm}$ の集光レ ンズを通しモノクロメータへ導入し，4レ一ザパルスの平均 を取った。特定波長の時間発展波形は，4〜16回の平均を取つ た。分光測定と同時作製した薄膜付可視・紫外透過特性と 赤外吸収特性を測定した。可視・禁外測定は可視紫外分光 光度計（島津UV-160）を用いた。基板は石英である。赤外 吸収特性の測定はフーリ工変換型赤外分光光度計（島津 FTIR 8200A) を用いた。基板はn型Si (100)である。測定にお いては，実験に用いた Si (100)基板の赤外透過率が低いため, 郝反射計測を行った。アブレーション及び成膜の条件を 表 1 に示す。

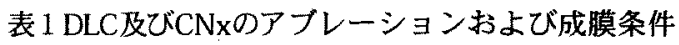
Talbe 1.Ablation and deposition conditions for DLC and CNx films.

\begin{tabular}{|c|c|c|c|}
\hline \multirow[b]{2}{*}{ 背景ガス } & \multicolumn{2}{|c|}{ DLC薄膜 } & \multirow{2}{*}{$\frac{\mathrm{CNx} \text { 薄膜 }}{\mathrm{N}_{2}}$} \\
\hline & $\mathrm{H}_{2}$ & $\mathrm{He}$ & \\
\hline 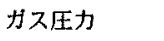 & $50 \sim 800 \mathrm{~m}$ Torr & $50 \sim 200 \mathrm{mTorr}$ & $20 \sim 200 \mathrm{mTorr}$ \\
\hline ターゲット & \multicolumn{3}{|c|}{$\begin{array}{c}\text { グラファイトターダット } \\
\text { (純度 } 99.999 \%)\end{array}$} \\
\hline $\begin{array}{l}\text { レーザフルエ } \\
\text { ンス }\end{array}$ & \multicolumn{3}{|c|}{$4 \sim 8 \mathrm{~J} / \mathrm{cm}^{2}$} \\
\hline $\begin{array}{l}\text { レーザパルス } \\
\text { 数 }\end{array}$ & \multicolumn{3}{|c|}{ 9000〜36000ショット } \\
\hline $\begin{array}{l}\text { ターゲット基 } \\
\text { 板問距触 }\end{array}$ & \multicolumn{3}{|c|}{$40 \mathrm{~mm}$} \\
\hline 到達真空度 & \multicolumn{3}{|c|}{$5.0 \times 10^{7}$ Torr以下 } \\
\hline $\begin{array}{l}\text { 基板温度, } \\
\text { 負バイアス }\end{array}$ & \multicolumn{3}{|c|}{$\begin{array}{l}\text { 室温 } 300^{\circ} \mathrm{C} \\
0 \sim-300 \mathrm{~V}\end{array}$} \\
\hline 基板 & 石: & 英 & 石英， $\mathrm{Si}(100)$ \\
\hline
\end{tabular}

\section{3. 実験結果及び検討}

\section{<3・1〉 グラファイトターゲットによるレーザプラズマ プルームの発光特性}

図 2 にターゲット面上からの距離 $\mathrm{d}=10 \mathrm{~mm}$ における到達真 空度 $\left(5.0 \times 10^{-7} \mathrm{Torr}\right) ，$ ヘリウムガス $100 \mathrm{mT}$ orrにおける分光ス ペクトルを, 図 3 では図 2 において強い発光を示す $386.0 \mathrm{~nm}$ C 線（原子線）について到達真空度での時間発展波形を示 す。いずれもレーザフルエンスは6 $/ \mathrm{cm}^{2}$ である。496nmに現

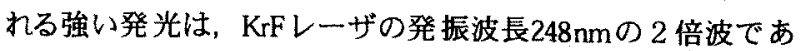
りプルームからの発光ではない。到達真空, ヘリウムガス 導入時の発光種はCI線，CII線（イオン線）のみの発光でス ペクトルに顕著な差はない。わずかな違いは, ヘリウムガ ス導入によりCI線発光種が減少することである。 $426.9 \mathrm{~nm}$, $437.1 \mathrm{~nm}$ は倠測されなくなり，538.0nmの発光も強度が低下し ている。逆にCI線発光は563.3nmなどが現れる。さらに到達 真空では658.8nmのCI線の発光はへリウム中では657.8nm, 658.3nmのCI線のイオン発光に変わっている。図 3 では表面 
上1mmにおける観測で 2つの発光ピークを観测した。レ一 ザ入射から 80nsで最初の発光ピークが, その後320ns後に大 きなピークが現れる。このような波形は，表面から5 $5 \mathrm{~mm}$ 上離れると観測されなくなる。ターゲット面上 $5 \mathrm{~mm}$ から $10 \mathrm{~mm}$ にかけての発光種の平均飛行速度は, 約 $5.0 \times 10^{1} \mathrm{~m} / \mathrm{s}$ と なる。 $10 \mathrm{~mm}$ から $20 \mathrm{~mm}$ までの平均速度も約 $3.3 \times 10^{4} \mathrm{~m} / \mathrm{s}$ で, 真 空中であるため発光種の減速は小さい。表面 $1 \mathrm{~mm}$ て観測さ れる最初のピークは，上記の平均速度より数倍速いため， 力学的な運動エネルギーは非常に大きい。これらの粒子束 はターゲットの極く近㥬で，衝突等により他の粒子にエネ ルギーを与え; 速度が緩和していくと考えられる。背景ガ スがある場合は衝突電稚を起こすので, ヘリウムガス導入 時にCI線が多く観測され，また再結合により線スペクトル が減少することが説明できる。

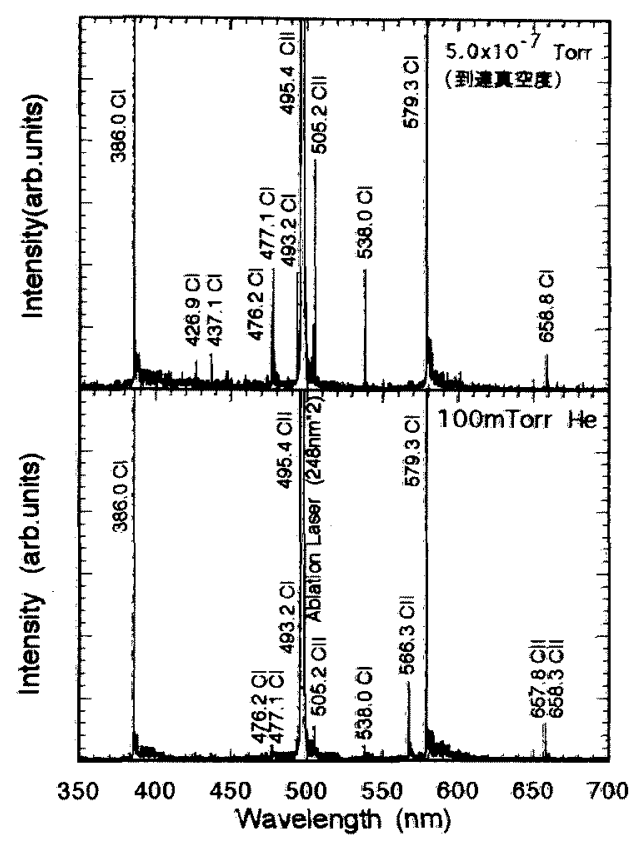

図2 到達真空度及びヘリウム導入時の発光スペクトル

Fig.2 Emission spectra of the plume at $5.0 \times 10^{-7}$ Torr and He ambient gas.

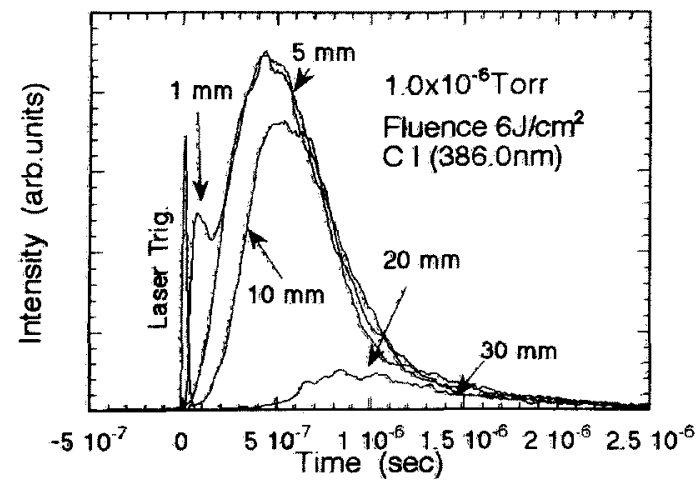

図3 CI (386.0nm)の発光の㭙間発展波形

Fig. 3 Temporal change of the emission intensity of Cl.
図4，図5に反応性ガスを導入した場合のスベクトルを示 す。图 4 は夕ーダット面上からの距離 $\mathrm{d}=10 \mathrm{~mm}$ にお沛る水素

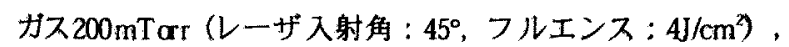
図5 は空素ガス $200 \mathrm{mT}$ arr (レーザ入射角 : $90^{\circ}$ 。フルエンス: $\left.6 \mathrm{~J} / \mathrm{cm}^{2}\right)$ に扔ける分光スペクトルを示す。

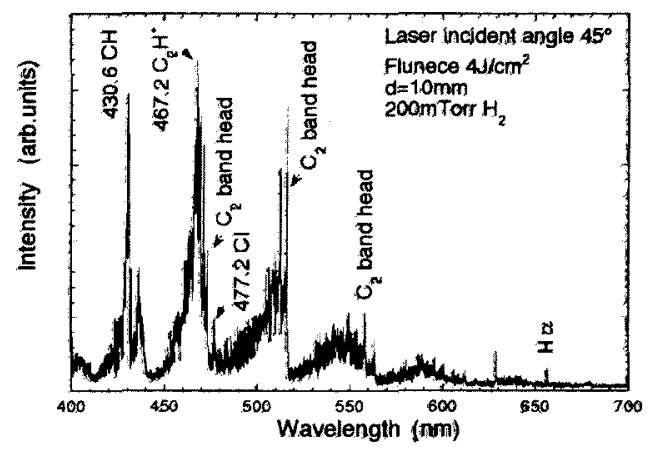

図4 水素ガス導入時のプラズマプルーム発光スペクトル Fig.4 Emission spectrum of the plume at $\mathrm{H}_{2}$ ambient gas.

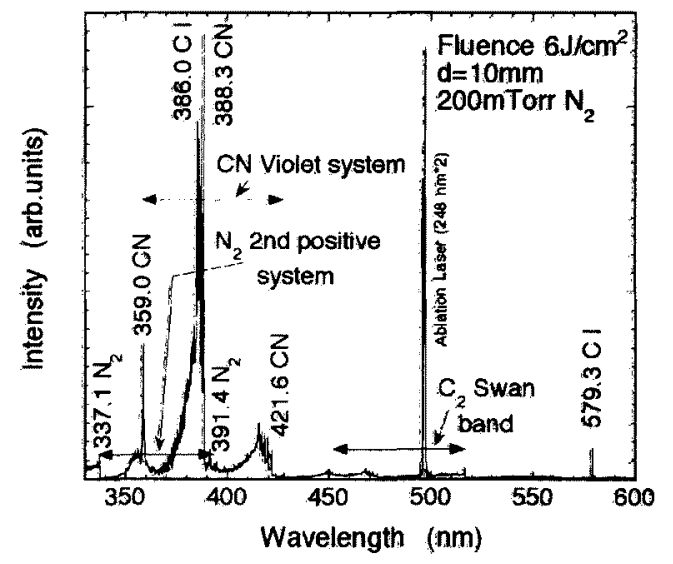

図 5 窒素ガス導入時のプラズマプルーム発光スペクトル Fig. 5 Emission spectrum of the plume at $\mathrm{N}_{2}$ ambient gas.

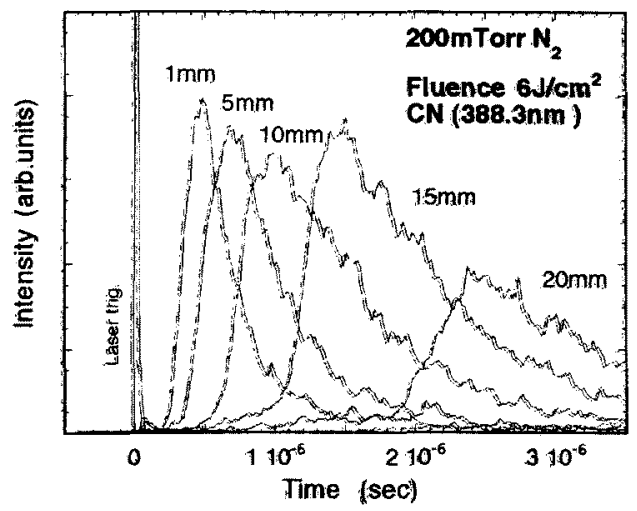

図6 CN $(388.3 \mathrm{~nm})$ の発光の時間発展波形

Fig.6 Temporal changes of emission intensity of CN $(388.3 \mathrm{~mm})$ 
水素ガスはアブレートされた炭素原子, イオンと気相反 応を起こし強いCH430nm systemの分子発光を示した。また $\mathrm{C}_{2}$ S wan Band $\left(\mathrm{d}^{3} \Pi_{\mathrm{B}} \rightarrow \mathrm{a}^{3} \Pi_{\mathrm{u}}\right)$ の発光が観測され， $\mathrm{C}_{2}$ が生成され ていることがわかる。このときのC $\mathrm{C}_{2}$ Swan Band発光強度は， CH430nm systemの発光強度上同程度である。

空素ガス導入時では CN Violet system $\left(B^{2} \Sigma^{+} \rightarrow X^{2} \Sigma^{+}\right)$ $(421.6 \mathrm{~nm}, 388.3 \mathrm{~nm}, 359.0 \mathrm{~nm})$ の発光が観測された。C $C_{2} S$ wan Ban溌光も観測され気相でC CN Viol et systemの発光は極めて強く, 388.3nmの発光をとら えるために, 分光器の光電子倍增管の感度を設定すると, 多くの他のスペクトル線はノイズに埋もれてしまう程であ る。岸素原子は気相で窒素ガスと反応するが，気相反応を 促進する $N_{2}$ 2nd positivesystem $\left(\mathrm{C}^{3} \Pi_{\mathrm{u}} \rightarrow \mathrm{B}^{3} \Pi_{\mathrm{g}}\right)$ の発光も観測さ 扎。 $\mathrm{N}_{2}$ 2nd positivesystemの発光は, $\mathrm{CN}$ systemの発光強度 か強いため，かなりの部分がマスクされているが，CN systemより長波長，短波長側の発光により同定できた。 $\mathrm{N}_{2}$ 1st positive systemは，発光が観測されなかった。 $\mathrm{N}_{2} や \mathrm{H}_{2}$ の反 応性ガスの導入により， C 分子の生成が促進されているこ とが分かる。これはKokai らの実験結果と一致している伯。 彼らのマススペクトルの分析ではC $C_{3}$ 以上分子の生成も確 認されており，成膜に影響を与えるものと思われる。本実 験においては水素ガス導入時に観測されるC $\mathrm{C}_{2}$ S wan Bandの発 光む, $\mathrm{d}=30 \mathrm{~mm}$ 付近においても観測されたことより，ターゲッ

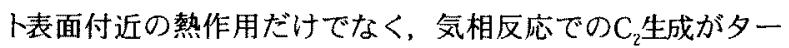
ゲットをかなり離れても起こっていることが分かった。し かし，ヘリウムガスの導入ではC れない。KrFレーザのアブレーションでは， $C_{2}$ 分子発光は反 忍性ガス導入時にだけ観測され，ヘリウムガスでは観測さ れない。これは活性ガス種だけの反応機構が, $C_{2}$ 分子生成 に関与している事を示してる。更に注目すべき事は, 公素 ガスの導入時は, $\mathrm{CN}$ Violet systemの発光に対し, $\mathrm{C}_{2} \mathrm{~S}$ wan Bandは $1 / 30$ 程度の発光強度しかないことである。水素の場 合はCH system $と C_{2}$ systemの発光強度はほぼ等しい。これは 以下のように考えられる。ターゲット近傍ではアブレート された炭素原子は反応性ガスとの3 体反応により炭素分子 を生成する。

$\mathrm{C}+\mathrm{C}+\mathrm{M}-\mathrm{C}_{2}+\mathrm{M}-\mathrm{-}$

Mを中性粒子とする。ターゲットから離れた地点での $\mathrm{C}_{2}$ Swan Band の観测を説明できる。

C,Hに関する電離過程としては

$\mathrm{H}_{2}+\mathrm{e}^{-}>2 \mathrm{H}+\mathrm{e}^{-}(8.9 \mathrm{eV})$
$\mathrm{H}+\mathrm{e}^{-}>\mathrm{H}^{+}+2 \mathrm{e}^{-}(13.6 \mathrm{eV})$
$\mathrm{C}+\mathrm{e}^{-}>\mathrm{C}^{+}+2 \mathrm{e}^{-}(11.3 \mathrm{eV})$
$\mathrm{C}+\mathrm{H}+\mathrm{e}^{-}>\mathrm{CH}+\mathrm{e}^{-}(-4.4 \mathrm{eV})$

などの反応によりCHは生成される。レーザ光 $248 \mathrm{~nm}$ の光子 エネルギーでは不十分であるが，放出されたターゲット近 傍の炭素原子の運動エネルギーは図 3 の波形からわかるよ うに，非常に高速なので， $10 \mathrm{eV}$ 程度のエネルギーの粒子も 生成され反応は促進する。しかし, 窒素原子線, イオン線 の発光は観測されていないことより窒素ガスの電離エネル
ギあをでには至っていない。窒素に関しては分子発光のみ である。したがってCNの生成はラジカル分子種 $C_{2}^{*}$ と $\mathrm{N}_{2}$ の反 応と考えるのが妥当である。

$\mathrm{C}_{2}{ }^{*}+\mathrm{N}_{2}^{*}>2 \mathrm{CN}^{*}$

(6)式の反応には当然中間過程が必要であるが,これを認め ると, 空素ガス導入時のCN Violet systemの発光に対し， $C_{2}$ Swan Bandの発光強度が小さいことが説明できる。

図 6 に窒素ガス $200 \mathrm{mT}$ orrの時のCN (388.3nm) の時間発展

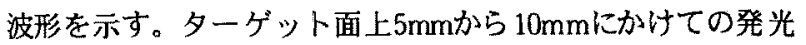
種の平均飛行速度は，約 $1.7 \times 10^{4} \mathrm{~m} / \mathrm{s}$ となる。 $10 \mathrm{~mm}$ から $20 \mathrm{~mm}$ までの平均速度は約 $6.7 \times 10^{3} \mathrm{~m} / \mathrm{s}$ で, 到達真空度の場合と比べ て発光種は衝突により大きく減速する。また，ターゲット 上1mmの観測では到達真空度の場合のように明らかな 2 成 分の発光にはならなかった。高速成分は $1 \mathrm{~mm}$ 点ではすで に(1) (6)の反応などににエネルギーを与えてエネルギー緩 和しているものと思われる。

\section{$<3 ・ 2>シ ュ タ ル ク$ 愊による電子密度の測定}

水素カス導入時のスペクトルにはH $\alpha(656.3 \mathrm{~nm})$ が観測 された。H $\alpha$ のスペクトルのシュタルク広がりから電子密度 を求めた。電子密度が比較的高い場合, 荷電粒子の電界に よって生じる光の波長の広がりは顕著になる。水素原子の 場合半值幅は近似的に

$$
\Delta \lambda(\AA)=8.16 \times 10^{-19}\left(1-0.7 N_{D}{ }^{-1 / 3}\right) \lambda_{0}{ }^{2}\left(n_{1}{ }^{2}-n_{2}{ }^{2}\right) N_{e}^{2 / 3}
$$
ここで $\mathrm{N}_{0}$ はデバイ球内の電子数， $n_{1}, n_{2}$ は遷移の上下両準位の 主量子数， $\lambda_{0}(\AA)$ は中心波長， $N_{\mathrm{e}}$ は電子密度 $\left(\mathrm{cm}^{3}\right)$ である。電 子密度を求めるには $N_{D}$ を先に求める必要があり，電子温度

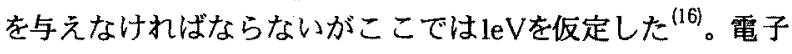
温度はN測定には余り敏感には効かず依存性は小さい。ター ゲットからの距離による密度変化を図 7 に示す。 $\mathrm{d}=10 \mathrm{~mm}$ 付 近における水素プラズマの密度は約 $5 \times 10^{16} \mathrm{~cm}^{3}$ となり反応に 充分な電子密度であることがわかる。

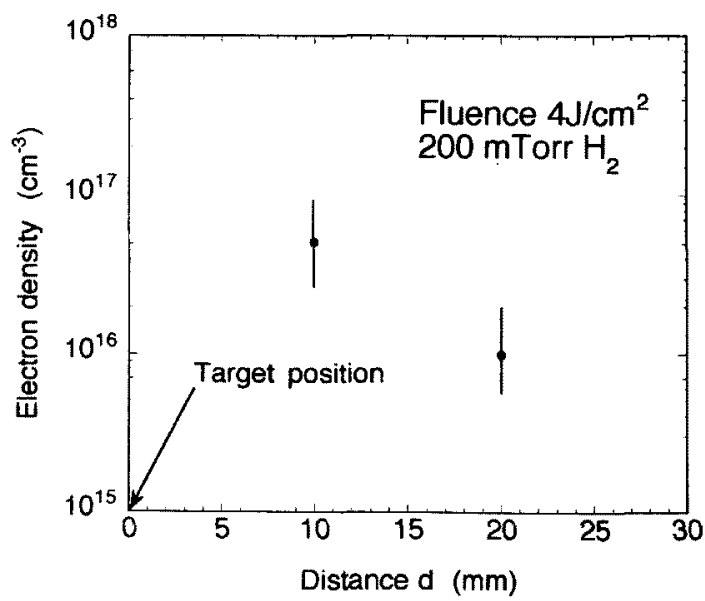

図7 ターゲットからの距離による電子密度の変化

Fig.7 Electron densities at various distance from the target surface. 


\section{$<3 \cdot 3>D L C$ 策膜の光学的特性}

ヘリウムガスおよび水素カスを導入し, フルエンス $8 \mathrm{~J} / \mathrm{cm}^{2}$ で成膜されたDLCの光学吸収特性を図 8 に示す。

最大到達真空度におけるDLCの成膜では可視, 紫外の透過 率は非常に低く, 光学ギャップの測定は困難であるが, へ リウムガス，及び水素ガスを導入することにより，光学ギャッ フ特性が向上する。おのおの $1.0 \mathrm{eVおよび20} \mathrm{eV}$ 光学ギャッ プがえられた。

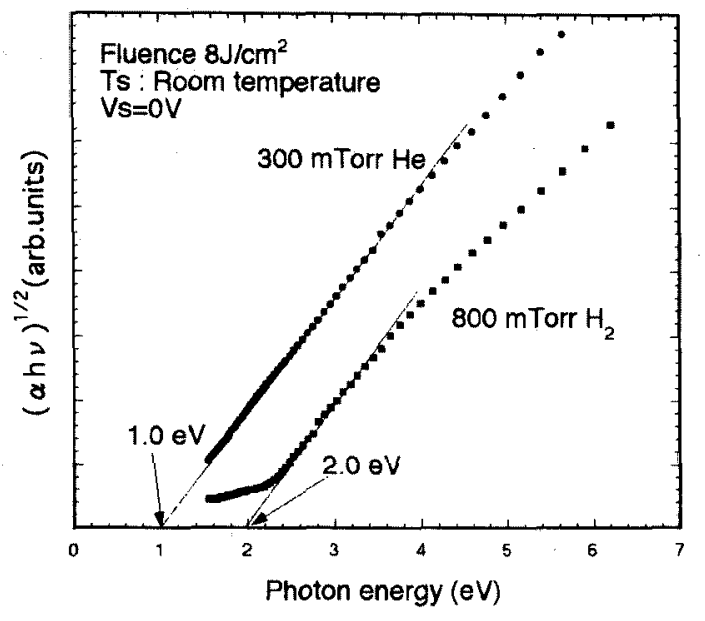

図 8 DLC 薄膜の光学吸収特性

Fig.8 Optical absorption characteristic of the DLC.

水素ガス導入時の光学特性の向上は, 炭素原子のダング リングボンドの水素原子による終端である。しかしヘリウ ムガス導入によっても光学特性の改善が可能である事が示 された。これは,ダングリングボンドの水素終端とは違 つ たメカニズムである。ヘリウムガス压とレーザフルエンス を変えた実験から，压力には適正值があり，またフルエン スの增大に伴い光学ギャップが大きくなることが測定され た。これはへりウムの導入により，炭素原子とへリウムガ スとの衝突によるイオン化が促進され，気相拉よび薄膜成 長時のイオン衝突により sp 結合が增大するためと考えてい る。このことはJin等によって，aCおよびCNx膜に対し低工 ネルギー (5〜 $100 \mathrm{eV})$ 炭素, 空素イオンビームを照射しイ オン衝㪍を与え，sp結合相の増加を確認した報告がある(17)。 ヘリウムとは質量差があるが，sp 結合相增大はイオン衝撃 が大きく関与していると考えられる。真空中に対するへリ ウムガス導入時の発光種及び強度の変化, 特にCI線の増大 が膜質に関与している事が確認さ扎た。

\section{$<3 \cdot 4>$ 窒素ガス中のCN薄膜成膜と赤外吸収特性}

窒素ガス導入時のターゲット表面付近の観測においても CN Violet systemは観測されており，CN分子生成反応は炭素 原子のアブレーションと殆ビ同時に起こることがわかる。 また， $C_{2}$ Swan band も観測されているので， $C_{2}$ 分子も生成さ れている。この条件に於ける $\mathrm{CN}$ 薄膜の成膜を行い赤外吸収
特性を調べた。典型的な吸収特性を図 9 に示す。図 9 では 炭素, 窒素相互の結合による吸収が現れる，2500〜 $500 \mathrm{~cm}^{-1}$ の波数域を示している。 $2120 \mathrm{~cm}^{-1}$ 付近にC $\equiv N$ N結合が確認さ れまた $1600 \mathrm{~cm}^{-1} に \mathrm{C}=\mathrm{N}$ 二重結合伸縮の幅広く大きな吸収を 観測した。1600 $\mathrm{cm}^{-1}$ にはC $=\mathrm{C}$ 二重結合伸縮も吸収を示すが， 水素, ヘリウムの背景ガスとして成膜した場合には $1600 \mathrm{~cm}^{-1}$ に吸収を観測しないことより， $\mathrm{C}=\mathrm{N}$ 二重結合の割合が多いと 考えられる。

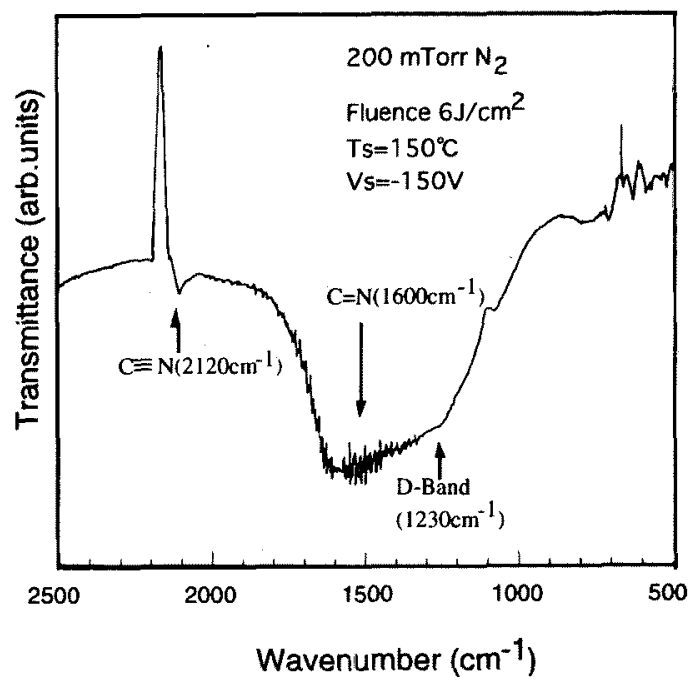

図 $9 \mathrm{CN}$ 薄膜のFTIRによる赤外吸収特性

Fig.9 A FTIR spectrum of the CNx film.

\section{4. むすび}

本論文では，グラファイトカーボンターゲットを様々な カス雺囲気でレーザアブレーションを行い，プラズマプルー ム中に含まれる発光粒子種の同定を行った。また，同時に DLCおよびCNx薄膜の成膜も行い，プラズマプルームと薄膜 特性を関連付けることを目指した。本論文の結論を以下に 示す。

(1) 真空, ヘリウムガス導入におけるアブレーションで は，炭素原子線，イオン線のみが発光し，C2などの分子ス ペクトルは観測されなかった。また，真空中ではターゲッ 卜付近では，2成分の速度を持ち，高速な放出粒子成分は ガスの電離／解離に関連している可能性が高い。

（2）水素カスを導入により分子発光としてCH430nmシス テム， $C_{2}$ Swan bandが観測された。空素ガスを導入した場合 は強いCN Violet systemの発光, および弱い $C_{2}$ S wan band $の$ 発 光が確認された。これにより炭素原子は反応性ガスがある とき，炭素分子を生成し気相中で水素，窒素と反応するが， さらに窒素は生成された炭素分子と気相反応しCN分子を生 成をしている可能性が高い。

(3) $\mathrm{H} \alpha$ スペクトルのシュタルク広がりより, プラズマ プルームの電子密度は $5 \times 10^{16} \mathrm{~cm}$ 程度である事が確認された。 
最後に本研究を遂行するにあたり，薄膜分析に御協力いた だいた，九州東海大学松本敏之助教授に感謝します。 (平成11年1月25日受付, 平成11年3月30日再受付)

\section{文献}

(1) S.Aoqui, C.S.Choi, Y.Yamagata, K.Ebihara : "YBaCuO superconducting thin films protected by diamondlike carbon films using $\mathrm{KrF}$ Excimer laser ablation ", Advances in Superconductivity VII (Springer-Verlag Tokyo 1995)

(2) C.B.Collins, F.Davanloo, D.R.Jander, T.J.Lee, H.Park \& J.H.You : "Microstructure of amorphic diamond films ",

J. Appl. Phys. 69 (11), 7862 (1991)

(3) F.Xiong, Y.Y.Wang, V.Leppert \& R.P.H.Chang :Pulsed laser deposition of amorphous diamond-like carbon films with ArF (193 nm) excimer laser ", J. Mater. Res. Vol. 8, No9, 2265 (1993)

(4) A.A.Voevodin, S.J.P.Laube \& D.Walck : " Pulsed laser deposition of diamond-like amorphous carbon films from graphite and polycarbonate target ", J. Appl. Phys. 78 (6), 4123 (1995)

(5) S.Aoqui, T.Ikegami, Y.Yamagata, K.Ebihara : " Optical emission study of the laser plasma plume produced during diamondlike carbon thin film preparation :, Thin Solid Films (1998)

(6) Kazuhiro Yamamoto, Yoshinori Koga, Shuzo Fujiwara \& Fimio Kokai : "The fraction of $\mathrm{Sp}^{3}$ bonding in carbon thin films prepared using pulsed laser deposition ", Jpn. J. Appl. Phys. Vol.36, 1333 (1997)

(7) S.S.Harilal, C.V.Bindhu, P.N.Nampoori \& C.P.G.Vallabhan : "Influence of ambient gas on the temperature and density of laser produced carbon plasma ", Appl. Phys. Lett. 72 (2), 167 (1998)

(8) D.L.Pappas, K.L.Saenger, J.Bruley, W.Krakow \& J..J.Cuomo : "Pulsed laser deposition of diamond-like carbon films ", J. Appl. Phys. 71 (11), 5675 (1992)

(9) E.Aldea, A.Paola, G.Dinescu, A.Luches \& A.Perrone : "Optical emission diagnostic of laser-induced plasma during CNx film deposition ", Jpn. J. Appl. Phys. Vol.36, 4686 (1997)

(10) Z.M.Ren, P.N.Wang, Y.C.Du, Z.F.Ying \& F.M.Li : "Optical studies on the deposition of carbon nitride films by laser ablation ", Appl. Phys. A. 65, 407 (1997)

(11) F.Kokai : "Optical emission spectra from laser ablation of graphite at $266 \mathrm{~nm}$ and $1064 \mathrm{~nm}$ under a magnetic field ", Jpn. J. Appl. Phys. Vol.36, 3504 (1997)

(12) S.S.Harilal, Riju C.Lssac, C.V.Bindhu, V.P.N.Nampoori \& C.P.G.Vallabhan : "Emission characteristics and dynamics of $\mathrm{C}_{2}$ from laser produced graphite plasma ", J. Appl. Phys. 81 (8), 3637 (1997)

(13) S.S.Harilal, Riju C.Lssac, C.V.Bindhu, V.P.N.Nampoori \& C.P.G.Vallabhan : "Temporal and spatial evolution of $\mathrm{C}_{2}$ in laser induced plasma from graphite target ", J. Appl. Phys. 80 (6), 3561 (1996)

(14) S.S.Harilal, Riju C.Lssac, C.V.Bindhu, V.P.N.Nampoori \& C.P.G.Vallabhan : "Optical emission studies of $\mathrm{C}_{2}$ species in laser-produced plasma from carbon ", J. Phys. D: Appl. Phys. 30, 1703 (1997)

(15) 小海文夫 "グラファイトのレーザアブレーションにおけ るC, C2 およびC3の検出と解析", T.IEE Japan, Vol.117-C, No.9, 1194 (1997)

(16) D.B.Chrisey, G.K.Hubler :"Pulsed laser deposition of thin films", Jhon Wiley \& Sons, Inc (1994)

(17) Y-S.Jin, T.Shibata, Y.Matsuda, H.Fujiyama : "Effects of nitrogen ion beam irradiation on a-C and $\mathrm{CNx}$ thin films ", Jpn. J. Appl. Phys. Vol.37, L1260 (1998)

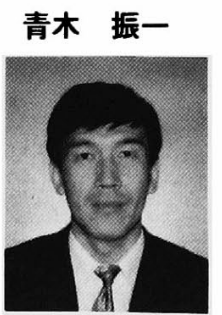

(正員) 1957 年3月28日生まれ。83年3 月筑波大学大学院理工学研究科修士課 程修了。85年2月沼津工業校等専門学校 電気工学科助手, 87 年同講師, 93 年同助 教授，97年4月熊本工業大学工学部電気 工学科助教授, 現在に至る。プラズマ レーザによる高硬度薄膜作製プロセス の開発に関する研究に従事。応用物理 学会, 日本物理学会, 情報処理学会, 応用数理学会会員。

池上 知顯
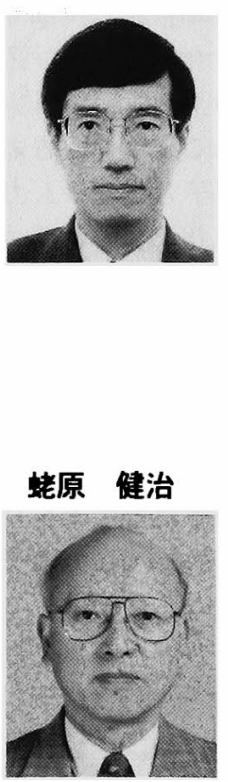

（正員） 1955年9月1日生まれ。80年3月 九州大学大学院工学研究科修士課程修 了。同年4月同大学工学部電気工学科助 手，88年4月熊本大学工学部電気情報工 学科助手，90年2月同助教授，96年7月よ り1年間ミシガン州立大学客員助教授, 現在に至る。レーザ誘導放電, レーザ による酸化物超伝導体薄膜作製プロセ スの開発，太陽光発電などに関する研 究に従事。工学博士。応用物理学会, プラズマ・核融合学会, IEEE会員。

（正員） 1941年10月27日生まれ。67年 3月九州大学大学院修士課程修了。同年 大阪市立大学理学部助手, 69年山口大学 工学部講師, 75年熊本大学工学部助教授、 84年2月同教授，現在に至る。 高温超伝導薄膜作製プロセスの開発と 超伝導の応用, プラズマプロセス工学 に関する研究に従事。工学博士。 電子情報通信学会, 応用物理学会, 静 電気学会, 日本物理学会, MRS学会 会員。 